\title{
The Filling Evaluation of Lateral Canals in the Root Canal Obturation
}

\section{Avaliação do Preenchimento de Canais Laterais na Obturação do Canal Radicular}

\author{
Angelica Godinho Ceribellia; Sandrine Bittencourt Berger ${ }^{\mathrm{a}}$; Thais Maria Freire Fernandes ${ }^{\mathrm{a}}$; Eloisa Aparecida Carlesse \\ Paloco ; Murilo Baena Lopes ${ }^{\text {a }}$ Alejandra Hortencia Miranda González; ;uilherme Genovez-Júniora; \\ Ricardo Danil Guiraldo*a;
}

${ }^{a}$ Unopar, Stricto Sensu Graduate Program in Dentistry. PR, Brazil.

*E-mail: rdguiraldo@gmail.com

\begin{abstract}
The anatomical complexity of root canals, for instance, their shape, curvature and radius curvature diversity, as well as the presence of high index isthmus and lateral canals are important factors to be taken into consideration in endodontic therapy. Thus, the aim of the present study was to assess complete filling of simulated lateral canals with two different endodontic cements. Eight anterior teeth extracted due to periodontal reasons were used in the experiment. Lateral canals were opened with $1 / 4$ spherical-shaped carbide drill 4 mm away from the root apex. Teeth were subjected to X-ray in anteroposterior position. The root canals of these teeth were prepared with the aid of a 25.08 reciprocating system in electrically driven motor X Smart Plus for its working length by using $2.5 \%$ sodium hypochlorite as irrigating solution. The teeth were divided into 2 groups $(n=4)$ according to different endodontic cements (AH Plus or Bio C Sealer). Root canals were dried with paper points, afterwards were filling with medium cone and different endodontic cements. The complete filling of simulated lateral canals was assessed based on new digital radiographs taken after teeth filling. The simulated lateral canals were not completely filled, regardless of the used endodontic cement. Results have shown that the different assessed cements did not fill the simulated lateral root canals.
\end{abstract}

Keywords: Endodontics. Root Canal Filling. Root Canal Sealer Materials.

\section{Resumo}

A complexidade anatômica dos canais radiculares, por exemplo, sua forma, curvatura e diversidade da curvatura do raio, bem como a presença de istmo de alto índice e canais laterais, são fatores importantes a serem levados em consideração na terapia endodôntica. Assim, o objetivo neste estudo foi avaliar o preenchimento total de canais laterais simulados com dois diferentes cimentos endodônticos. Foram utilizados 8 dentes anteriores extraídos por razões periodontais. Foram confeccionados canais laterais com uma broca carbide esférica $1 / 4$ a uma distância de $4 \mathrm{~mm}$ do ápice radicular. Em seguida, os dentes foram radiografados no sentido anteroposterior. Os canais radiculares destes dentes foram preparados utilizando-se de um sistema reciprocante 25.08 acionados por motor elétrico X Smart Plus até o comprimento de trabalho utilizando hipoclorito de sódio 2,5\% como solução irrigante. Os dentes foram divididos em 2 grupos ( $n=4)$ de acordo com diferentes cimentos endodônticos (AH Plus ou Bio C Sealer). Os canais foram secos com pontas de papel absorvente, depois foram preenchidos com cone médio e diferentes cimentos endodônticos. O preenchimento total de canais laterais simulados foram avaliados a partir de novas radiografias digitais realizadas após obturação dos dentes. Os canais laterais simulados não foram completamente preenchidos, independentemente do cimento endodôntico utilizado, e os resultados demonstraram que os diferentes cimentos avaliados não preencheram os canais radiculares laterais simulados.

Palavras-chave: Endodontia. Obturação do Canal Radicular. Materiais Restauradores do Canal Radicular.

\section{Introduction}

Three-dimensional filling of the root canal system after its cleaning and modeling is the purpose of endodontic treatment (SCHILDER, 1967; TEDESCO et al., 2019). Several root canal filling materials and techniques have been developed (TANOMARU-FILHO, 2011) and studied. The aim of such studies is to completely fill the root canals and their ramifications (TANOMARU-FILHO et al., 2011). Different endodontic filling techniques were assessed in order to observe filling homogeneity (FRACASSI et al., 2013) and the volume of voids and gaps in root canal filling (ZOGHEIB et al., 2013). The success of endodontic treatments mainly depends on correct cleaning and modeling of the root canal system before the three-dimensional filling procedure is performed.
However, the anatomical complexity of root canals, for instance, their shape, curvature and radius curvature diversity, as well as the presence of high index isthmus (PÉCORA et al., 2013; CANDEIRO et al., 2019) and lateral canals are important factors to be taken into consideration in endodontic therapy. Depending on the filling technique to be used, the ability to fill lateral canals becomes an important parameter to assess root canal filling materials for clinical use. Simulated lateral canals can be produced in artificial (VENTURI et al., 2005) or natural teeth (GOLDBERG; ARTAZA; SILVIO, 2001; ALMEIDA et al., 2007). Root canal filling can be assessed through radiographic examinations (GOLDBERG; ARTAZA; SILVIO, 2001), dental decalcification, compensation methods or through the combination of different methods (ALMEIDA et al., 2007). 
Root canal filling with gutta-percha, zinc oxide-eugenol cement or calcium hydroxide, or with epoxy resin-based cement has shown the potential of these composites to fill the root canal system (GOLDBERG; ARTAZA; SILVIO, 2001; ALMEIDA et al., 2007). Several thermoplastic root canal filling techniques have been developed to help professionals accomplishing the effective filling of the root canal system (LEONARDO et al., 2004). The technique known as thermomechanical compaction was introduced by Mc Spadden and modified by Tagger et al. (1984) Based on this technique, thermomechanical compactors are used to heat and plasticize gutta-percha, due to their ability to make lateral and apical pressure. However, previous studies have shown endodontic treatment flaws due to failure in lateral canal filling. Such failures often require the conduction of apicectomy or even the extraction of the dental element (WEINE, 1984). Thus, the aim of the present study was to evaluate the complete filling of simulated lateral canals with two different endodontic cements.

\section{Material and Methods}

The study was subjected to the Research Ethics Committee of University North Parana (CEPAE-10841319.9.0000.0108; Protocol \#3.440.309). Eight anterior teeth, which were extracted for periodontal reasons, were used in the experiment. The teeth were cleaned with pumice stone and dental Robinson's brush after extraction and stored in $0.5 \%$ chloramine $\mathrm{T}$ solution for 7 days. Next, they were stored in distilled water at $4^{\circ} \mathrm{C}$ until the beginning of the experiment.

\subsection{Teeth preparation}

The coronary portion of the teeth was sectioned with the aid of a diamond disk (American Burrs, Palhoça, SC, Brazil). Lateral canals were produced with $1 / 4$ spherical-shaped carbide drill (Kavo Burrs, Joinville, SC, Brazil) $4 \mathrm{~mm}$ away from the root apex. The teeth were subjected to X-ray in anteroposterior position for $0.3 \mathrm{~s}$, at $20-\mathrm{cm}$ firing distance and $0^{\circ}$ angle in Ion 70x Mobile Spine X-ray unit (PROCION Indústria e Comércio Ltda., Ribeirão Preto, SP, Brazil), at $70 \mathrm{Kv}$ and 8 $\mathrm{mA}$, coupled with FIT-T1 digital micro image sensor (Acteon Micro Image, Indaiatuba, SP, Brazil).

Working length (WL) was established by inserting \#10 k-file (DentsplyMaillefer, Baillagues, Switzerland) until foramen. The root canals were prepared by using a 25.08 reciprocating system (WaveOne; DentsplyMaillefer, Baillagues, Switzerland) in electrically driven motor X Smart Plus (DentsplyMaillefer, Baillagues, Switzerland) for its WL - 2.5\% sodium hypochlorite (Asfer, Sao Caetano do Sul, SP, Brazil) was used as irrigating solution. Final irrigation was performed based on recommendation by the manufacturer for Easy Clean use (Easy Dental Products, Belo Horizonte, MG, Brazil). Irrigation with $2.5 \%$ sodium hypochlorite was carried out with the aid of an Easy Clean tip: 3 activation times (20- second activation); irrigation with EDTA (Maquira, Maringá, PR, Brazil): 3 activation times (20-second activation); and irrigation with sodium hypochlorite, again. The canals were dried with paper points (DentsplyMaillefer, Baillagues, Switzerland).

The teeth were divided into 2 groups $(n=4)$; the filling procedure in all groups was based on the single cone technique: selecting a medium cone (DentsplyMaillefer, Baillagues, Switzerland). Teeth in Group 1 were filled with AH Plus (Dentsply De Trey, Konstanz, Germany); it was placed in the root canal with the aid of a gutta-percha cone. Group 2 was subjected to filling with Bio C Sealer (Angelus, Londrina, PR, Brazil), which was introduced in the root canal with the aid of a gutta percha cone. The assessed teeth were subjected to $\mathrm{X}$-ray again (as previously described); the complete filling of simulated lateral canals was evaluated through qualitative analysis after teeth filling.

\section{Results and Discussion}

Main root canal ramifications, such as lateral canals, have great clinical importance for endodontic therapy, mainly when they are associated with lateral lesions. The objective of root canal treatments is to fill the root canal system and to isolate microorganisms found in inaccessible areas that do not have access to space and nutrients. Thus, the normal condition of periapical tissue is restored (GUIGAND et al., 2005). Among other requirements, it is necessary using endodontic cements that present good flow and composition based on inert materials (PÉCORA et al., 2002; DE DEUS et al., 2002). Two different endodontic cements were used in the present study (AH Plus or Bio C Sealer).

The single cone filling technique needs a single guttapercha cone and endodontic cements to its performance; it is simple, of easy domain and timesaving. This technique does not allow longitudinal or lateral pressure, which is possible to achieve through the use of techniques based on condensation (BLUM; ESBER; MICALLEF, 1997; CAPAR et al., 2015). Therefore, the risk of root fracture decreases in teeth filled based on the single cone filling technique. Thermal damage is not expected to happen in the periodontal membrane when the single cone filling technique is applied, although such damage may occur when the warm vertical technique is adopted (VIAPIANA et al., 2015). However, because this technique does not require gutta-percha thermocompaction throughout the process, space filling depends on the action of the cement itself when it is compared to other techniques (WU; OZOK; WESSELINK, 2000). Therefore, the herein performed final irrigation was based on irrigating solution activation with Easy Clean tip to remove the smear layer formed during chemical-mechanical preparation. It was done in order not to interfere in the bond between dentin and cement.

Several studies have reported endodontic success after lateral canal filling. Different filling techniques have been 
proposed to fill these canals (SCHILDER, 1967; DULAC et al., 1999). Although some studies question the idea that the applied technique has large effect on the number of filled lateral canals (GOLDBERG; ARTAZA; SILVIO, 2001; NICHOLS, 1963), other studies have shown that vertical gutta-percha compaction increases lateral canal filling capacity (SCHILDER, 1967; GOLDBERG; ARTAZA; SILVIO, 2002). The present study was based on using the single cone filling technique with vertical compression, but none of the used cements were able to completely fill the simulated lateral canals, a fact that could be minimized if other techniques were adopted. However, warm vertical compaction accounts for greater gutta-percha volume and lower rates of voids than cold lateral compaction (KELEŞ et al., 2014). Thus, it is necessary using specific apparatuses to place the endodontic cement in the lateral canals. Future studies should provide alternatives for the filling of lateral canals through the use of these apparatuses.

Anatomical complexity, such as dentinal tubules, isthmus, lateral canals and apical ramifications protect bacteria from chemomechanical procedures (VERA et al., 2012). Endodontic cements enable the "entompement" of residual microorganisms in areas inaccessible to instruments and gutta-percha filling (TUNCER; TUNCER; GÖKYAY, 2014; VERTUAN et al., 2018). Cement penetration depends on many factors, including smear layer removal effectiveness, cement physical and chemical properties and root canal system anatomy (TUNCER; TUNCER, 2012).

Flow rate is another essential characteristic of cements, since it contributes to cements' dentinal penetration. This physical property indicates cements' ability to penetrate areas of complex anatomy (GROSSMAN, 1976) besides, it is an important factor for the filling of lateral or accessory canals. Endodontic cements' flow potential depends on their composition and setting time; moreover, such flow can be improved by pressure (GROSSMAN, 1976). AH Plus is considered the gold standard sealant in comparison to other brands or chemical compositions (PIAI et al., 2018). AH Plus and Bio C Sealer endodontic cements recorded similar results in root canals filling, in the present study (Figures 1 and 2). Thus, based on Figure 1, the lateral canals were not completely filled with AH Plus endodontic cement and Figure 2 evidences that they were also not completely filled with Bio C Sealer endodontic cement.
Figure 1 - Teeth filled with AH Plus endodontic cement without completely filled root canals

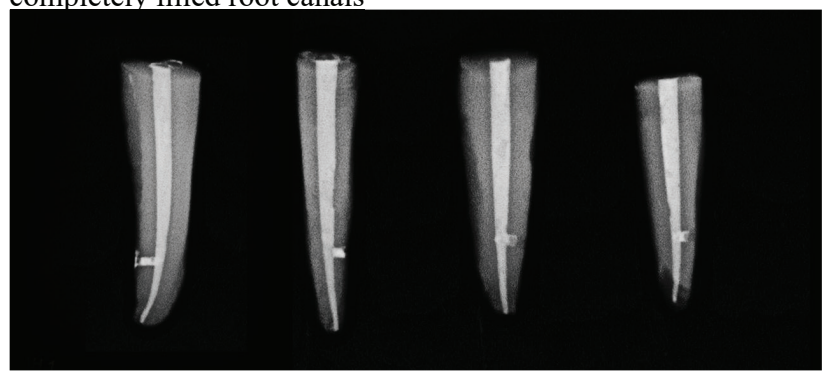

Source: Authors.

Figure 2 - Teeth filled with Bio C Sealer endodontic cement without completely filled root canals

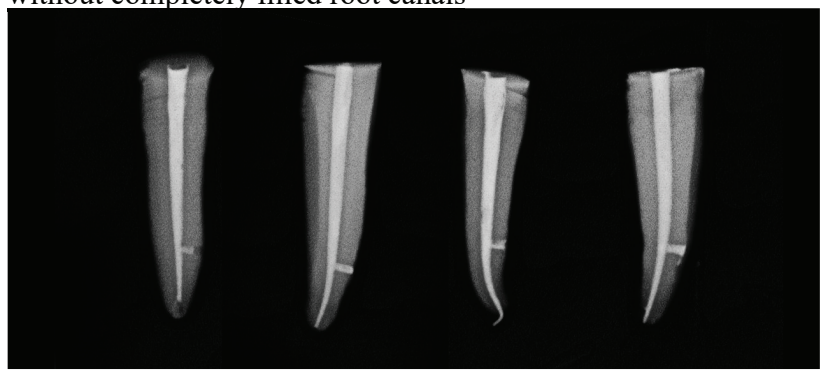

Source: Authors.

The diameter of root canal ramifications ranged from 50 to $150 \mu \mathrm{m}$. Such small diameters and ramifications within the root canal system can affect the canal-filling procedure (SANT'ANNA-JUNIOR et al., 2015). The opening of larger lateral canals ( $1.4 \mathrm{~mm}$ diameter) proposed in the present study resulted from the difficulty in working with canals so small that they could feature a study limitation. However, such outcome does not disqualify the study because, theoretically, this technique would make it easier to fill these lateral canals; although it was not observed in the present study. Based on the current results, there was no complete filling of simulated lateral canals with different endodontic cements.

\section{Conclusion}

According to findings in the present study that used the single cone technique as filling procedure, the different cements studied did not fill the simulated lateral root canals.

\section{References}

ALMEIDA, J.F.A. et al. Filling of artificial lateral canals and microleakage and flow of five endodontic sealers. Int Endod J, v.40, n.9, p.692-699, 2007. doi: 10.1111/j.1365-2591.2007.01268.x

BLUM, J.Y.; ESBER, S.; MICALLEF, J.P. Analysis of forces developed during obturations. Comparison of three gutta-percha techniques. J Endod, v.23, n.5, p.340-345, 1997.

CANDEIRO et al. Penetration of bioceramic and epoxy-resin endodontic cements into lateral canals. Braz Oral Res, v.33, p.e049, 2019. doi:10.1590/1807-3107bor-2019.vol33.0049

CAPAR, I.D. et al. Effects of root canal preparation, various filling techniques and retreatment after filling on vertical root fracture and crack formation. Dent Traumatol, v.31, n.4, p.302307, 2015. doi: 10.1111/edt.12154

DE DEUS, G.A. et al. Penetração intratubular de cimentos 
endodônticos. Braz Oral Res, v.16, n.4, p.332-336, 2002. doi: 10.1590/S1517-74912002000400009

DULAC, K.A. et al. Comparison of the obturation of lateral canals by six techniques. J Endod, v.25, n.5, p.376-380, 1999.

FRACASSI, L.D. et al. Evaluation of the quality of different endodontic obturation techniques by digital radiography. Clin Oral Investig, v.17, n.1, p.97-103, 2013. doi: 10.1007/s00784012-0675-7

GOLDBERG, F.; ARTAZA, L.P.; SILVIO, A. Effectiveness of different obturation techniques in the filling of simulated lateral canals. J Endod, v.27, n.5, p. 362-364, 2001.

GOLDBERG, F.; ARTAZA, L.P.; SÍLVIO, A. Influence of calcium hydroxide dressing on the obturation of simulated lateral canals. $J$ Endod, v.28, n.2, p.99-101, 2002.

GROSSMAN, L.I. Physical properties of root canal cements. $J$ Endod, v.2, n.6, p.166-175, 1976.

GUIGAND, M. et al. Comparative study of two canal obturation techniques by image analysis and EDS microanalysis. Br Dent $J$, v.198, n.11, p.707-711, 2005.

KELEŞ, A. et al. Micro-CT evaluation of root filling quality in oval-shaped canals. Int Endod J, v.47, n.12, p.1177-1184, 2014. doi: 10.1111/iej.12269

LEONARDO, M.R. et al. Effect of different rotary instrumentation techniques and thermoplastic filling on apical sealing. $J$ Appl Oral Sci, v.12, n.1, p.89-92, 2004.

NICHOLS, E. Lateral radicular disease due to lateral branching of the root canal. Oral Surg Oral Med Oral Pathol, v,16, p.839845, 1963.

PÉCORA, J.D. et al. Detection of root canal isthmuses in molars by map-reading dynamic using CBCT images. Braz Dent J, v.24, n.6, p.569-574, 2013. doi: 10.1590/0103-6440201302380

PÉCORA, J.D. et al. Influence of the spatulation of two zinc oxide and eugenol based sealers on the obturation of lateral canals. Braz Oral Res, v.16, n.2, p.127-130, 2002.

PIAI, G.G. et al. Penetrability of a new endodontic sealer: A confocal laser scanning microscopy evaluation. Microsc Res Tech, v.81, n.11, p.1246-1249, 2018. doi: 10.1002/jemt.23129

SANT'ANNA-JUNIOR, A. et al. Filling of simulated lateral canals with gutta-percha or thermoplastic polymer by warm vertical compaction. Braz Oral Res, v. 29, n.1, p01-06, 2015. doi:

\subsection{0/1807-3107BOR-2015.vol29.0056}

SCHILDER, H. Filling root canals in three dimensions. Dent Clin North Am, p.723-744, 1967.

TAGGER, M. et al. Evaluation of the apical seal produced by a hybrid root canal filling method, combining lateral condensation and thermatic compaction. $J$ Endod, v.10, n.7, p.299-303, 1984. doi: 10.1016/S0099-2399(84)80183-1

TANOMARU-FILHO, M. et al. Effectiveness of gutta-percha and Resilon in filling lateral root canals using the Obtura II system. Braz Oral Res, v.25, n.3, p.205-209, 2011.

TEDESCO, M. et al. Correlation between bond strength to dentin and sealers penetration by push-out test and CLSM analysis. Braz Dent J, v.30, n.6, p.555-562, 2011. doi: 10.1590/01036440201902766

TUNCER, A.K.; TUNCER, S. Effect of different final irrigation solutions on dentinal tubule penetration depth and percentage of root canal sealer. $J$ Endod, v.38. n.6, p.860-863, 2012. doi: 10.1016/j.joen.2012.03.008

TUNCER, A.K.; TUNCER, S.; GÖKYAY, S.S. Correlation between sealer penetration into dentinal tubules and bond strength of two new calcium silicate-based and an epoxy resin-based, endodontic sealer. J Adhes Sci Tech, v.28, n.7, p.702-710, 2014.

VENTURI, M. et al. An in vitro model to investigate filling of lateral canals. $J$ Endod, p.31, n.12, p.877-881, 2005.

VERA, J. et al. One-versus two-visit endodontic treatment of teeth with apical periodontitis: A histobacteriologic study. $J$ Endod, v.38, n.8, p.1040-1052, 2012.

VERTUAN, G.C. et al. Evaluation of physicochemical properties of a new root canal sealer. J Endod, v.44, n.3, p.501-505, 2018.

VIAPIANA, R. et al. Investigation of chemical changes in sealers during application of the warm vertical compaction technique. Int Endod J, v.48, n.1, p.16-27, 2015.

WEINE, F.S. The enigma of the lateral canal. Dent Clin North Am, v.28, n.4, p.833-852, 1984.

WU, M.K.; OZOK, A.R.; WESSELINK, P.R. Sealer distribution in root canals obturated by three techniques. Int Endod J, v.33, n.4, p.340-345, 2000.

ZOGHEIB, C. et al. Comparative micro-computed tomographic evaluation of two carrier-based obturation systems. Clin Oral Investig, v.17, n.8, p.1879-1883, 2013. 